\title{
SONDERJYDSKE ARB
}

I. halvbind

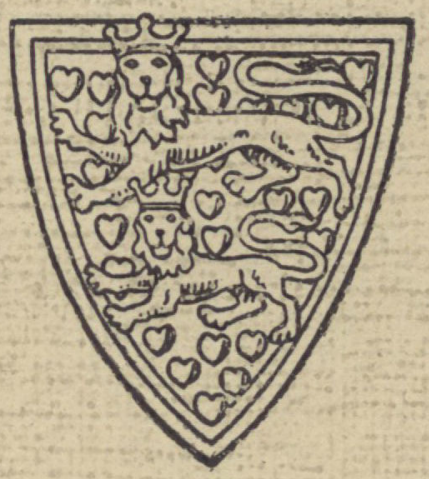

1949

\section{Udgivet af}

Historisk samfund for Sønderjylland 


\section{AKTIESELSKABET \\ VEJLE TEXTILFABRIK}

\section{Hejmdals Bogtrykkeri}

A A B ENRA A

leverer

Tryksager at enhver Art

Telefon 3132 (5 Linjer)

N. J. Gotthardsen:

\section{Paa Vagt for Danmark}

Et nationalpolitisk Testamente

Kr. 3.50

Danskerens Forlag,

Aabenraa

\section{HOLLAND}

6 dage $245 \mathrm{kx}$. Afgang hver uge

\section{PARIS}

11 dage $490 \mathrm{kx}$. Afgang hver 14. dag

Tag med paa turene, der afgaar hver 8. og 14. dag, og oplev foråret i Amsterdam og Paris. - Aarets bedsie rejsemaaneder sydpaa.

Tilmeld Dem snarest, flere af sommerturene overtegnede.

Brochure paa forlangende.

M. Høirup, skolebestyrer, Grindsted, telef. $40 \mathrm{og}$

L. J. Lauritzen, Tønder, telef. 520.

\section{Roman fra}

Sydslesvig

\section{Willy-August}

\section{Linnemann}

\section{Mit land lå imørke}

\author{
Kr. 7,75
}

Forfatteren til "Sangen om de lyse nætter" og "Natten før freden" skildrer i en fængslende roman mennesker og tilstande i Sydslesvig efter den anden verdenskrig. Romanen giver de psykologiske, historiske og nationale forudsætninger for stillingen $i$ dag.

„En eminent betydningsfuld bog om skæbnetimen, der nu er inde for folket og landet."

Professor Hans Brix

1 Berlingske Aftenavis.

Willy-August Linnemanns romaner og skuespil er fore-

løbig ialt trykt $i$

\subsection{0}

GYLDENDA L 